\title{
Chromosome 20 long arm deletion in an elderly malformed man
}

\author{
F Shabtai, E Ben-Sasson, S Arieli, J Grinblat
}

\section{Cytogenetic \\ Laboratory, Hasharon \\ Hospital, Golda \\ Medical Centre, PO \\ Box 121, Petah-Tiqva \\ 49372, Israel. \\ F Shabtai}

\section{Department D, Beit \\ Rivka Geriatric \\ Centre, Petah-Tiqva, \\ Israel. \\ E Ben-Sasson \\ $S$ Arieli \\ J Grinblat}

\section{Department of}

Geriatrics, Hasharon

Hospital, Golda

Medical Centre,

Petah-Tiqva, Israel.

J Grinblat

Correspondence to

Dr Shabtai.

Received 24 March 1992.

Revised version accepted

1 June 1992.

\begin{abstract}
A 46,XY/46,XY, del(20)(q13 $\rightarrow$ q13.33) mosaicism was identified in a 68 year old man who had mild mental retardation and severe malformation of the limbs. The clinical findings of the patient are compared to those of the very few cases of $20 \mathrm{q}$ deletion published to date.

(f Med Genet 1993;30:171-3)
\end{abstract}

Constitutional anomalies of chromosome 20 are rare. A few cases have been reported with ring $20,{ }^{1}$ a few with complete or partial trisomy (mostly of the short arm), ${ }^{2}$ and a very few with partial deletion of the short or the long arm..$^{3-5}$ Deletions of the long arm in particular are extremely rare.

We report here an additional case of partial $20 \mathrm{q}$ deletion (mosaic) in a malformed man.

\section{Case report}

A 68 year old malformed male, of Jewish Iranian origin, was admitted to hospital after a road accident. He was known to be mildly mentally retarded from childhood. $\mathrm{He}$ had married a cousin and fathered four normal children. His wife had no record of abortions or abnormal births.

On physical examination the patient had an asymmetrical face, pterygium of both eyes, a low set, malformed left ear, a prominent nasal bridge, prognathism, a short neck, and a flat occiput. Diffuse hirsutism and upper and lower limb malformations were noted. The hands were in an abducted position. On the right hand, the second and fourth digits overlapped the third, and the thumb bones were hypoplastic. On the left hand, congenital absence of the thumb was noted.

$X$ rays of the limbs showed dislocation of the radioulnar joint, deformity of the distal radius, and hypoplasia of the scaphoid and metacarpal bones of the thumb in the right arm. In the left arm, dislocation of the wrist, hypoplastic proximal radius, absence of the distal radius, and congenital absence of the thumb were noted. The right leg was normal, whereas the left one had pes cavus with toe clawing and coxa vara (figs 1 and 2).

The right leg, injured in the accident, was swollen and showed a giant haematoma. During hospitalisation, lymphoedema developed in this leg. Among other studies, CT scan of both legs was performed, and showed lymphoedema secondary to the injury in the right leg. In the left leg, muscular atrophy was noted, subcutaneous and intramuscular adipose tissue replacing muscular tissue. No abnormalities were noted on neurological examination.

A holosystolic murmur was heard over the cardiac apex. Electrocardiogram showed ischaemic changes in the lateral wall, but no symptoms of cardiac disease were present. Echo Doppler studies of the heart showed mild

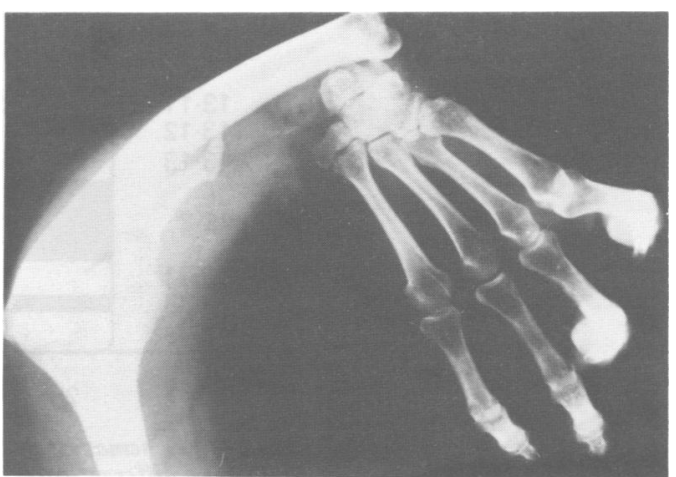

Figure $2 \mathrm{X}$ ray of the left hand.
Figure 1 Malformations of the patient's head and limbs.

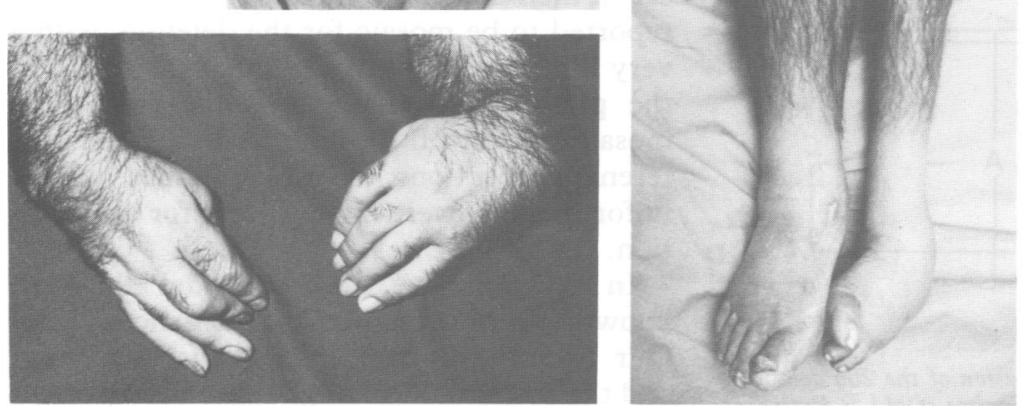


Data on the reported patients with chromosome 20 deletion.

\begin{tabular}{|c|c|c|c|c|c|}
\hline & Ahmed $^{8}$ & Fraisse $e t a l^{b}$ & Petersen et al & Present case & Porfirio et $a l^{1}$ \\
\hline $\begin{array}{l}\text { Region } \\
\text { Sex } \\
\text { Age } \\
\text { Clinical } \\
\text { findings }\end{array}$ & $\begin{array}{l}\text { q- (?) } \\
\text { M } \\
69 \text { y } \\
\text { Short stature } \\
\text { Microcephaly } \\
\text { Flat occiput } \\
\text { Slanting eyes } \\
\text { Epicanthic folds } \\
\text { Widely spaced nipples } \\
\text { Normal dermatoglyphics } \\
\text { Hypogonadism and } \\
\text { hydrocele } \\
\text { Mild heart failure } \\
\text { Peripheral vascular disease } \\
\text { Cervical spondylosis } \\
\text { Osteoarthropathy }\end{array}$ & $\begin{array}{l}\text { q13.11 } \rightarrow \text { qter } \\
\text { M } \\
3 \text { mth } \\
\text { Large face } \\
\text { Prominent, short forehead } \\
\text { Hirsutism } \\
\text { Short neck } \\
\text { Flat occiput } \\
\text { Slanting eyes } \\
\text { Epicanthic folds } \\
\text { Large, anteverted nostrils } \\
\text { Broad nasal bridge } \\
\text { Long upper lip } \\
\text { Thick lower lip } \\
\text { Low set, malformed, large } \\
\text { ears } \\
\text { High arched palate } \\
\text { Microretrognathia } \\
\text { Neurological problems } \\
\text { Psychomotor retardation } \\
\text { Severe malformations of } \\
\text { limbs }\end{array}$ & $\begin{array}{l}\mathrm{q} 11.23 \rightarrow \mathrm{q} 13.11 \\
\mathrm{M} \\
4 \mathrm{y} \\
\text { Developmental retardation } \\
\text { Mild facial dysmorphism } \\
\text { Strabismus } \\
\text { Broad nasal bridge } \\
\text { Macrostomia } \\
\text { Low set ears } \\
\text { Febrile seizures } \\
\text { Heart murmur } \\
\text { Adenosine deaminase } \\
\quad \text { deficiency }\end{array}$ & $\begin{array}{l}\text { q13.11 } \rightarrow \text { q13.33 (mosaic) } \\
\text { M } \\
68 \text { y } \\
\text { Asymmetrical face } \\
\text { Short neck } \\
\text { Flat occiput } \\
\text { Pterygium of eyes } \\
\text { Prominent nasal bridge } \\
\text { Low set, malformed left } \\
\text { ear } \\
\text { Prognathism } \\
\text { Mitral valve prolapse } \\
\text { Hirsutism } \\
\text { Severe malformation of } \\
\text { limbs }\end{array}$ & $\begin{array}{l}\text { Ring q13 } \rightarrow \text { qter } \\
M(\mathrm{n}=8), \mathrm{F}(\mathrm{n}=6) \\
6 \text { mth to } 27 \mathrm{y} \\
\text { No distinct dysmorphic } \\
\text { syndrome } \\
\text { Microcephaly } \\
\text { Developmental retardation } \\
\text { Large fontanelles } \\
\text { Epicanthus } \\
\text { Strabismus } \\
\text { Prominent nose } \\
\text { Large ears } \\
\text { Micrognathia } \\
\text { Short fifth fingers } \\
\text { Cryptorchidism } \\
\text { Epileptic seizures }\end{array}$ \\
\hline
\end{tabular}

A

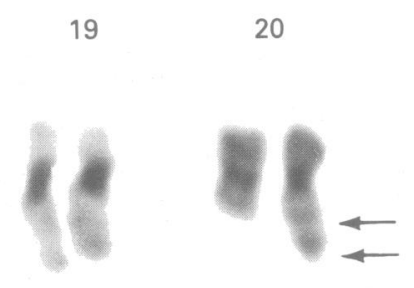

B

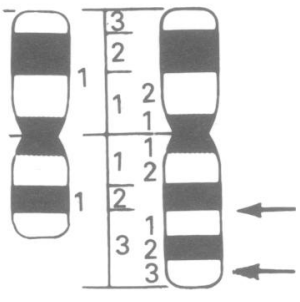

20
Figure 3 The $20 q$ deletion $(A)$ and its schematic representation $(B)$.

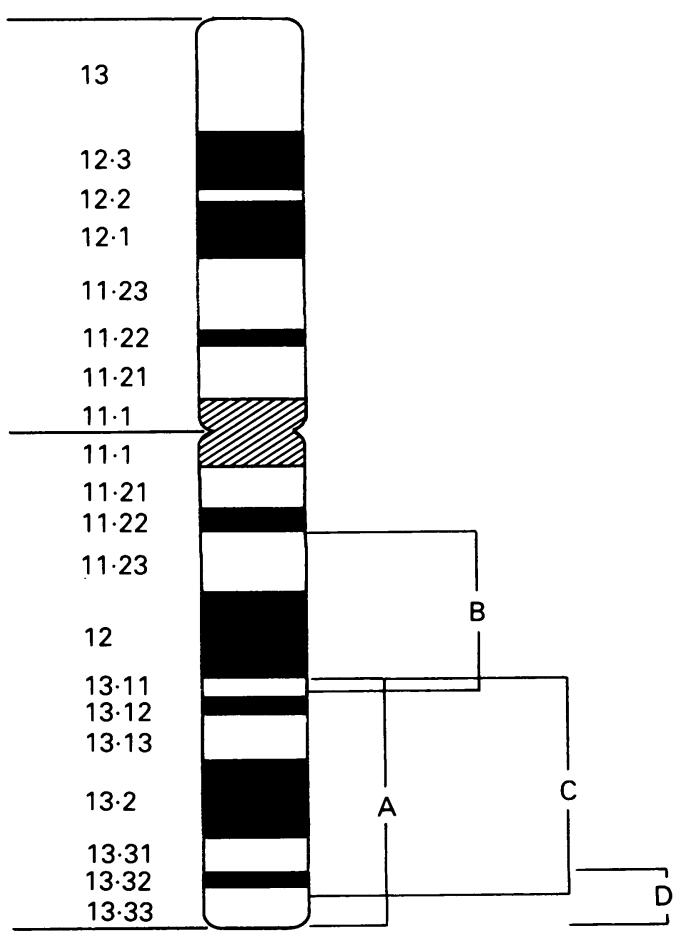

20 Figure 4 Schematic representation of the $20 q$ deletions
reported in different cases: $A$ Fraisse et al, ${ }^{6} B$ Petersen et al, ${ }^{7} C$ present case, $D$ Porfirio et al. ${ }^{\prime}$ widening of the left atrium and the left ventricle, moderate thickening of the left ventricular walls, and prolapse of the posterior leaflets of the mitral valve with flail.

The patient was referred for chromosome analysis which, to the best of our knowledge, had not been performed before.

\section{CYTOGENETIC STUDIES}

Peripheral blood lymphocytes were cultured by standard methods using GTG, AOG, QFQ, and CBG staining on two occasions during his hospitalisation, each time in triplicate using three different flasks.

One hundred and fifty-four cells were examined altogether. All the cells had 46 chromosomes. In $4 \%$ of them, derived from different cultures, a $20 \mathrm{q}$ deletion, interpreted as $\operatorname{del}(20)(\mathrm{q} 13.11 \rightarrow \mathrm{q} 13.33$ ), was observed (fig 3). Permission was not obtained for examination of other tissues.

\section{Discussion}

Only two cases of $20 \mathrm{q}$ deletion, verified by banding techniques, have been reported to date. ${ }^{67} \mathrm{~A}$ case of long arm deletion of an $\mathrm{F}$ group chromosome (which might have been 20) was reported before the banding era. ${ }^{8} \mathrm{With}$ due caution we include this case for comparison in our discussion.

The patients reported by Fraisse $e t a l^{6}$ and by Petersen $e t a \bar{l}$ were very young children, whereas the patient of $\mathrm{Ahmed}^{8}$ and our own are in their sixties. Our patient is the only one reported to be mosaic for the deletion, with a very low percentage of abnormal cells $(4 \%)$ in the presence of severe malformations. The mosaicism may have appeared in quite different proportions in other tissues which, unfortunately, were not available for examination.

In addition, we must consider the well known phenomenon of decreasing mosaicism. ${ }^{9}$ Our patient was examined in his later years and the abnormal line might have been present in much higher proportions at a younger age. 
Data on the three reported patients and on our own are listed in the table. The patients do not have very much in common, but this is not surprising, considering that different portions of the chromosome 20 long arm are involved in the deletion. Furthermore, as in other cases of deletions, we must consider the influence of hemizygous genes on the undeleted homologue. We have no definition of the missing portion in the case described by Ahmed. ${ }^{8}$ In the case reported by Petersen et $a l^{7}$ the missing segment was q11.23 $\rightarrow$ q13.11, in that reported by Fraisse $e t$ al ${ }^{6} \mathrm{q} 13.11 \rightarrow \mathrm{qter}$, and in our case $\mathrm{q} 13.11 \rightarrow \mathrm{q} 13.33$ as shown in fig 4 .

Both the patient of Fraisse $e t a l^{6}$ and that of Petersen et al had adenosine deaminase (ADA) deficiency, which led Petersen et $a l$ to conclude that the ADA gene must be located at $20 \mathrm{q} 13.1$. It would have been of interest to test the activity of ADA and other enzymes ( $\mathrm{s}$ adenosyl-homocysteine hydrolase, topoisomerase I) in our patient. However, it was felt that the results might prove inconclusive because of the very low proportion of abnormal cells. No immunological deficit was present in our patient.

The chromosomal deletion is very similar in the patient of Fraisse $e t a l^{6}$ and in our patient. However, comparison of the clinical features is complicated by the fact that the first is a baby and the second is an elderly man. Both of them have a short neck, flat occiput, short forehead, low set, large ears, and severe malformations of the limbs. Hirsutism and retardation cannot be evaluated in a baby, but cannot be excluded in the case of Fraisse et al. ${ }^{6}$

Neurological problems as described in other cases were not present in our patient. This may be because of the chromosomal mosaicism which may have different distribution in different tissues and did not affect neurological tissue in our case. Alternatively, it may indicate that the very terminal portion of $20 \mathrm{q}$ (q13.33) is related to neurological development. Indeed, the cases reported of ring chromosome 20 presenting minimal terminal deletions of $20 \mathrm{p}$ and small terminal deletions of $20 \mathrm{q}$ usually suffer arrested mental development and mental retardation and have epileptic seizures. ${ }^{1}$

In conclusion, it seems possible to delineate a 20q- syndrome where the deletion includes the $\mathrm{q} 13.12 \rightarrow \mathrm{q} 13.32$ region, the major features being retardation, severe malformations of the limbs, short neck, flat occiput, and mild facial dysmorphism.

Reports of additional cases will probably help in understanding the particular contribution of each band and subband of the deletion.

The authors wish to thank Mrs Dvora Klar and Ronit Eliav for skilful technical assistance, and the Photographic Department for the photographic work.

1 Porfirio B, Valorani MG, Giannotti A, Sabetta G, Dallapiccola B. Ring 20 chromosome phenotype. $\mathcal{F}$ Med Gene 1987;24:375-7.

2 Pierquin G, Herens C, Dodinval P, et al. Partial trisomy 20q due to paternal $t(8 ; 20)$ translocation. Case report and review of the literature. Clin Genet 1988;33:386-9.

3 Schinzel A. Catalogue of unbalanced chromosome aberrations in man. Berlin: De Gruyter, 1984:674-80.

4 Kiss P, Osztovics M. Deletion of the short arm of chromosome 20. Clin Genet 1988;33:140-3.

5 Silengo MC, Lopez Bell G, Biagioli M, Franceschini P. Partial deletion of the short arm of chromosome 20 : $46, \mathrm{XX}$, del $(20)(\mathrm{p} 11) / 46, \mathrm{XX}$ mosaicism. Clin Genet 1988;33:108-10.

6 Fraisse J, Bertheas MF, Frere F, Lauras B, Rolland MO, Brizard CP. Un nouveau syndrome: del(20)(q13-qter). Localisation segmentaire de gene de l'adenosine deaminase (ADA). Ann Genet (Paris) 1981;24:216-9.

7 Petersen MB, Tranebjaerg L, Tommerup N, Nygaard P, Edwards $\mathrm{H}$. New assignment of the adenosine deaminase gene locus to chromosome $20 \mathrm{q} 13.11$ by study of a patien with interstitial deletion 20q. f Med Genet 1987;24:93-6.

8 Ahmed M. Long-arm deletion of $19 / 20$ chromosomes. Lancet 1972;i:451.

9 Wilson MG, Towner JW, Forsman I. Decreasing mosaicism in Down's syndrome. Clin Genet 1980;17:335-40. 